We are grateful to Dr R Foster, Pfizer Central Research, for devising the methodology and providing the capsules of oxamniquine.

${ }^{1}$ Shaw JR, Brammer KW. The treatment of experimental schistosomiasis with a combination of oxamniquine and praziquantel. Trans $R$ Soc Trop Med Hyg 1983;77:39-40.

2 Teesdale CH, Amin MA. A simple thick-smear technique for the diagnosis of Schistosoma mansoni infection. Bull WHO 1976;54:703-5.

${ }^{3}$ Pugh RNH. A filtration method for schistosome egg quantification. Ann Trop Med Parasitol 1978;72:387-8.

4 Pugh RNH, Teesdale CH. Single-dose oral treatment in urinary schistosomiasis: a double-blind trial. Br Med f 1983;286:429-32.

${ }^{5}$ Dias LCS, Pedro RJ, Deberaldini ER. Use of praziquantel in patients with schistosomiasis mansoni previously treated with oxamniquine and/or hycanthone: resistance of Schistosoma mansoni to schistosomicidal agents. Trans $R$ Soc Trop Med Hyg 1982;76:652-9.

(Accepted 10 June 1983)

Department of Tropical Medicine, Liverpool School of Tropical Medicine, Liverpool L3 5QA

R N H PUGH, MRCP, DTM\&H, lecturer (seconded to the Ministry of Health, Malawi)

National Bilharzia Control Programme, Ministry of Health, Lilongwe 3, Malawi

C H TEESDALE, MSC, PHD, bilharzia control adviser

Correspondence to: Dr R N H Pugh, Ministry of Health, PO Box 30377, Capital City, Lilongwe 3, Malawi.

\section{Clostridium difficile and its toxin in healthy neonates}

Clostridium difficile and its associated toxin are related to pseudomembranous colitis but their presence in the stools of healthy neonates has been intriguing and demanded further study. ${ }^{1}$ This strictly anaerobic bacillus was first described in 1935 in the stools of four out of 10 normal breast fed infants in the first 10 days of life. ${ }^{2}$ It is rarely found in healthy adults. ${ }^{3}$ We reported a pilot study ${ }^{4}$ showing a $30 \%$ incidence of $C$ difficile in infants aged under 1 month. This present the stools of healthy babies in the first 28 days of life. By the end of the fourth week nearly half were colonised. There were no significant differences between breast fed and bottle fed babies; between those born by normal delivery, instrumental delivery (forceps or breech), or caesarean section; or between those born after short rupture of membranes ( $0-4$ hours) and long rupture of the membranes (4-20 hours). There was, however, a significant clustering of positive cases in one of the postnatal wards (ward A) compared with the other two $(\mathrm{p}<0.05$ by the Fisher exact probability test for samples 1 and 2 , but no significant difference for sample 3 ).

\section{Comment}

The clustering we found may indicate that the organism is acquired from the environment rather than from the birth canal of the mother, or that one colonised baby may easily contaminate a ward with the spore forming organisms. Samples from the hands of staff and from equipment did not yield $C$ difficile. Babies and nursing staff did not move from one ward to another. Only the medical staff attended all three wards. All the babies went home between the second and 10th day of life.

In none of the stool samples was the cytotoxin of $C$ difficile found. This is in contrast to the results of Viscidi et al, who found toxin in about one quarter of cases. ${ }^{3}$ In our study some strains of $C$ difficile did, however, produce toxin in culture medium. Of the samples taken during the fourth week of life 26 yielded $C$ difficile and, of those, eight produced toxin in culture. Probably the environment plays an important part in the production of $C$ difficile toxin and this may be why the administration of antibiotics enhances the toxin producing ability of the organism in vivo. Further studies are necessary to elucidate the environmental factors which encourage toxin formation in vitro and in vivo.

The isolates of $C$ difficile were indistinguishable by colonial morphology, antibiotic sensitivity, and fatty acid pattern on gas liquid chromatography. It has been suggested that analysis of stool specimens by gas liquid chromatography is a useful screening test for the presence of $C$ difficile. ${ }^{5}$ We examined stool specimens after preliminary incubation in cooked meat broth and of 177 samples screened for $C$ difficile by gas liquid chromatography 52 were positive but only 42 could be confirmed as containing the organism by further culture. All 10 cases not so confirmed were from bottle fed babies. Organisms giving a positive trace for isocaproic acid included $C$ sporogenes, $C$ sordellii, and $C$ bifermentans. This finding calls into question the use of gas liquid chromatography as the sole method of screening for the presence of $C$ difficile in clinical practice.

Details of $C$ difficile isolations from 59 healthy babies sampled on three occasions after birth

\begin{tabular}{|c|c|c|c|c|c|c|c|c|}
\hline \multirow[b]{2}{*}{ Sample } & \multicolumn{4}{|c|}{ No $(\%)$ of stool samples with $C$ difficile } & \multicolumn{4}{|c|}{ No $(\%)$ with toxin in culture medium } \\
\hline & $\begin{array}{l}\text { Ward A } \\
(\mathrm{n}=27)\end{array}$ & $\begin{array}{l}\text { Ward B } \\
(\mathrm{n}=10)\end{array}$ & $\begin{array}{l}\text { Ward C } \\
(\mathrm{n}=22)\end{array}$ & $\begin{array}{c}\text { Total } \\
(\mathrm{n}=59)\end{array}$ & $\begin{array}{l}\text { Ward A } \\
(\mathrm{n}=27)\end{array}$ & $\begin{array}{l}\text { Ward B } \\
(n=10)\end{array}$ & $\begin{array}{l}\text { Ward C } \\
(n=22)\end{array}$ & $\begin{array}{c}\text { Total } \\
(\mathrm{n}=59)\end{array}$ \\
\hline $\begin{array}{l}1 \text { (day } 1 \text { or } 2) \\
2 \text { (days } 5 \text { to } 7) \\
3 \text { (days } 21 \text { to } 28)\end{array}$ & $\begin{array}{r}4(15) \\
9(33) \\
15(56)\end{array}$ & $\begin{array}{l}0(0) \\
1(10) \\
3(30)\end{array}$ & $\begin{array}{l}0(0) \\
2(9) \\
8(36)\end{array}$ & $\begin{array}{c}4(7) \\
12(20) \\
26(44)\end{array}$ & $\begin{array}{l}0(0) \\
2(7) \\
3(11)\end{array}$ & $\begin{array}{l}0(0) \\
0(0) \\
2(20)\end{array}$ & $\begin{array}{l}0(0) \\
1(5) \\
3(14)\end{array}$ & $\begin{array}{l}0(0) \\
3(5) \\
8(14)\end{array}$ \\
\hline
\end{tabular}

study clarifies the time related colonisation of normal babies with this organism.

\section{Methods and results}

Stool samples from 59 healthy babies, none of whom had received antibiotics, were taken on three occasions during the neonatal period. All faecal samples were examined for neutralisable $C$ difficile toxin by the use of Hep 2 cells at an initial dilution of $1 / 10$. All samples were inoculated into cooked meat broth supplemented with cysteine, haemin, and menadione and incubated for 48 hours at $37^{\circ} \mathrm{C}$. Gas liquid chromatography was performed on ether extracts of the culture medium supernatant. Those samples showing a peak for isocaproic acid were subcultured on to $C$ difficile agar containing cycloserine and cefoxitin (Oxoid), and colonies of the $C$ difficile were tested for toxin production. The results were analysed according to the method of feeding, delivery, length of ruptured membranes before delivery, and the ward in which the babies were nursed until their discharge home. A limited environmental survey was performed on one of the wards. The floor of the nurseries, pieces of equipment, and bed pan macerator were sampled with moistened swabs, which were then incubated in cooked meat broth and subcultured on to $C$ difficile agar. Finger impressions from staff were taken directly on to $C$ difficile agar.

The results (table) showed an increase in the carrier rate of $C$ difficile in
' Larson HE, Price AB, Honour P, Borriello SP. Clostridium difficile and the aetiology of pseudomembranous colitis. Lancet 1978;i:1063-6.

2 Hall IC, O'Toole E. Intestinal flora in newborn infants with description of a new pathogenic anaerobe. Bacillus difficilis. Am $\mathcal{F}$ Dis Child 1935; 49:390-402.

${ }^{3}$ Viscidi $R$, Willey $S$, Bartlett JG. Isolation rates and toxigenic potential of Clostridium difficile isolates from various patient populations. Gastroenterology $1981 ; 81: 5-9$.

' Richardson SA, Brookfield DSK, French TA, Gray J. Pseudomembranous colitis in a 5 week old infant. $B r$ Med $\mathcal{f} 1981 ; 283: 1510$.

${ }^{5}$ Potvliege C, Labbé M, Yourassowsky E. Gas liquid chromatography as screening test for Clostridium difficile. Lancet 1981 ;ii:1105.

North Staffordshire Maternity Hospital, Stoke on Trent ST4 7PX $S$ A RICHARDSON, $\mathrm{MB}$, DCH, registrar in paediatrics

Public Health Laboratory Service and Microbiology Laboratory, Stoke on Trent ST4 7PX

P A ALCOCK, AIMLS, medical laboratory scientific officer

J GRAY, MRCPATH, DIPBACT, director

Correspondence to: Dr J Gray.

(1)

(1)

